\title{
Reforms could boost conservation banking by landowners
}

\author{
by David Bunn, Mark Lubell and \\ Christine K. Johnson
}

California pioneered the first conservation banking program in the nation in 1995. In contrast to the regulatory approach that penalizes landowners for harming protected species, conservation banking creates a market incentive for landowners to conserve wildlife. We investigated the implementation of the California Conservation Banking Program including a preliminary assessment of factors that limit the program's potential, both as an effective approach to conserving wildlife and as an economically rational option for ranchers and other landowners. We then surveyed the majority of wildlife agency conservation bank staff and conservation banking practitioners, and analyzed monitoring programs and ecological parameters of all approved banks. Most of the major challenges facing the Conservation Banking Program are linked to three fundamental problems: (1) the lack of clear standards and regulations, (2) the lack of adequate funding for dedicated wildlife agency coordinators and (3) the inefficiency and ecological constraints of managing stand-alone banks. Many of the challenges inhibiting conservation banking could be eliminated or reduced by enacting standards in statutes as well as by implementing a regional approach to planning for future sites.

Cons onservation banking provides a mechanism for ranchers and other landowners to receive income for managing their lands to benefit wildlife. California established the first conservation bank program in the nation and is recognized as a world leader in implementing biodiversity offsets as a means to conserve species (Mead 2008). Modeled

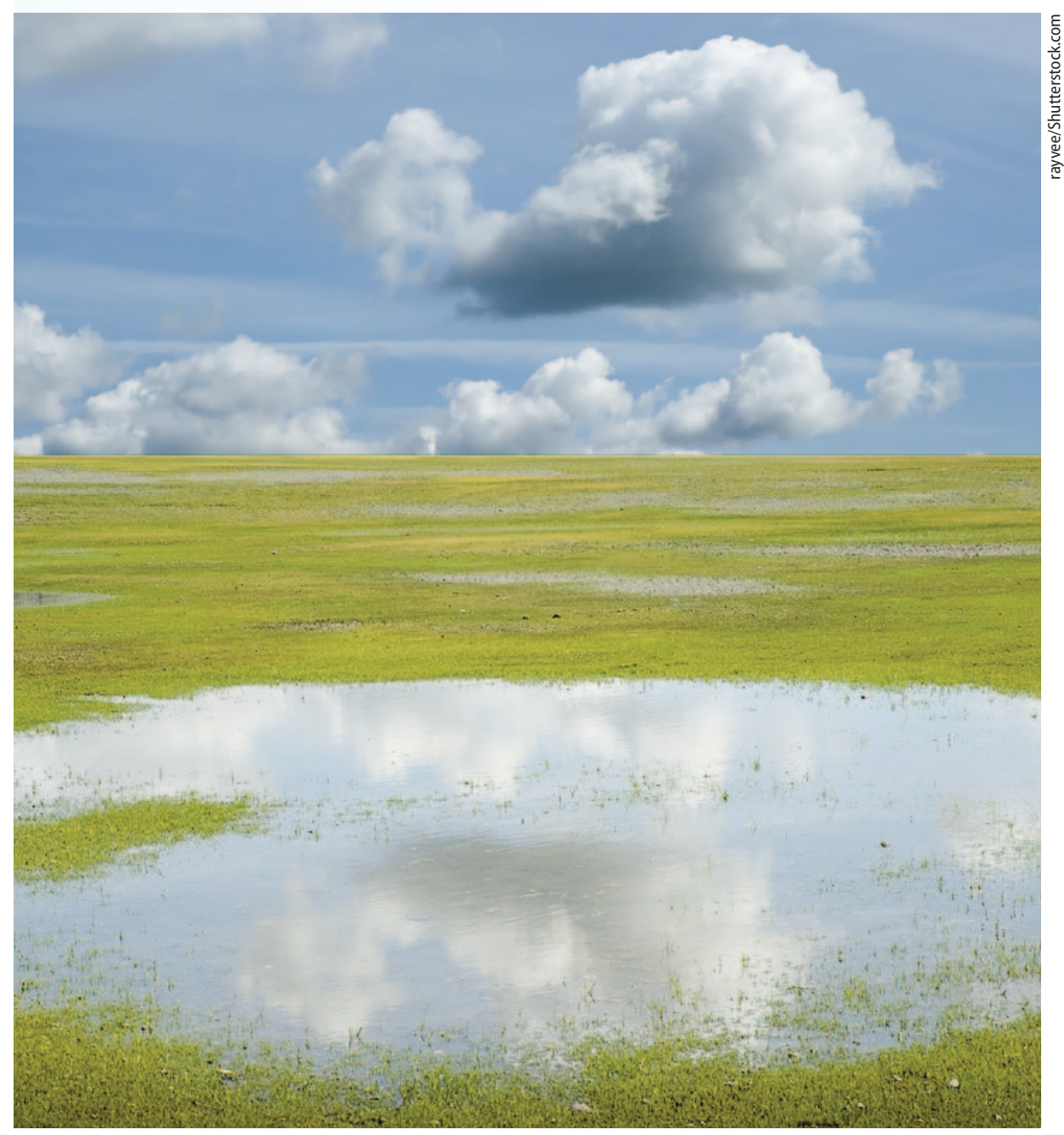

Conservation banks protect vernal pools on the Santa Rosa Plain and in the Central Valley. The California program mitigates impacts of development projects on endangered species and is modeled on the federal wetlands mitigation bank program.

on the federal wetlands mitigation bank program, conservation bank programs are applied to mitigating impacts of development projects on endangered species and species of concern. Conservation banks are publicly or privately owned lands that are protected in perpetuity by fee title or easement and managed to provide habitat for at-risk species. The owner, or management firm owning the bank, is authorized by wildlife agencies to sell credits to developers to mitigate impacts of their proposed development projects on wildlife.

The 18-year-old California Conservation Banking Program, the largest such state program, was launched by a state executive policy rather than by legislation (Wheeler and Strock 1995). The purposes of the program are to (1) conserve important habitats and habitat linkages, (2) provide a better alternative to the piecemeal project-by-project mitigation approach, (3) take advantage of economies of scale not available to individual mitigation projects, (4) provide incentives for private landowners to protect species and (5) provide an additional funding mechanism for ecosystem reserves within regional conservation plans (Wheeler and Strock 1995). In 2003 the U.S. Fish and Wildlife Service released a guidance document for establishment and operation of conservation banks across the nation.

Online: http://californiaagriculture.ucanr.edu/ landingpage.cfm?article=ca.v067n02p86\&fulltext=yes doi: 10.3733/ca.v067n02p86 
In California, mitigation for development projects that harm wildlife is implemented through one of four mechanisms: (1) mitigation on a project-by-project basis, (2) mitigation within a multispecies regional plan (under the state Natural Community Conservation Planning Program, coupled with a Habitat Conservation Plan for federally listed species), (3) purchasing offset credits in a conservation bank (Mead 2008; Wheeler and Strock 1995) or (4) payment of in-lieu mitigation fees.

\section{Regional conservation planning}

Regional conservation planning is the most comprehensive approach to conserving species and natural communities. Large-scale regional conservation plans, as developed under the state Natural Community Conservation Planning Program, are designed to conserve habitat and ecosystem functions that are critical to sustain at-risk species covered by the plan over a large landscape (Calif. Fish \& Wildlife Code § 2800 et. seq.; Pollack 2001). A broad range of ecological considerations is incorporated into the design of regional conservation plans and the protected reserve sites within them. These considerations include the distribution of plant communities, size of habitat patches required by various species, vital corridors, heterogeneity of the landscape, water resource commitments and management, appropriate recreational uses of the lands, the network design of protected areas and reliable long-term management funding (Calif. Fish \& Wildlife Code $\S 2800$ et. seq.; Noss et al. 1997). In addition, Natural Community Conservation Plans (NCCPs) require a monitoring program capable of assessing the biological status of covered species and habitats, and the ecological performance of the conservation plan. Monitoring is also necessary to inform adaptive management (Atkinson et al. 2004; Calif. Fish \& Wildlife Code $\S 2800$ et. seq.).

\section{Conservation Banking Glossary}

Fee title or easement: Conservation banks may be protected in perpetuity either by purchase of fee title or by easements on the land to ensure it is managed for conservation values. A key decision is who will own the land or hold the easement. A conservation banker may initially own a bank but later transfer ownership to the California Department of Fish and Wildlife (CDFW) or to a nonprofit land management firm.

Credit and debit values: A credit is a unit used to quantify the species or habitat conservation values within a conservation bank. For example, 1 acre of habitat is often worth one credit. A debit is a unit used to quantify adverse impact to species or habitats of concern on lands being developed. The wildlife agencies decide how many credits must be purchased to offset the impact of a development project, and these terms are a requirement for mitigation and permit approvals.

Service area: The service area is a geographic region where the adverse impacts of development projects can be covered by a particular conservation bank. The service area should be justified based on ecological considerations, including watershed boundaries as well as the population structure and distribution of covered species, and must be approved by the wildlife agencies. In addition, conservation banks that offer credits for multiple species may have more than one service area. Bankers are critically interested in the service area because it determines the potential market for

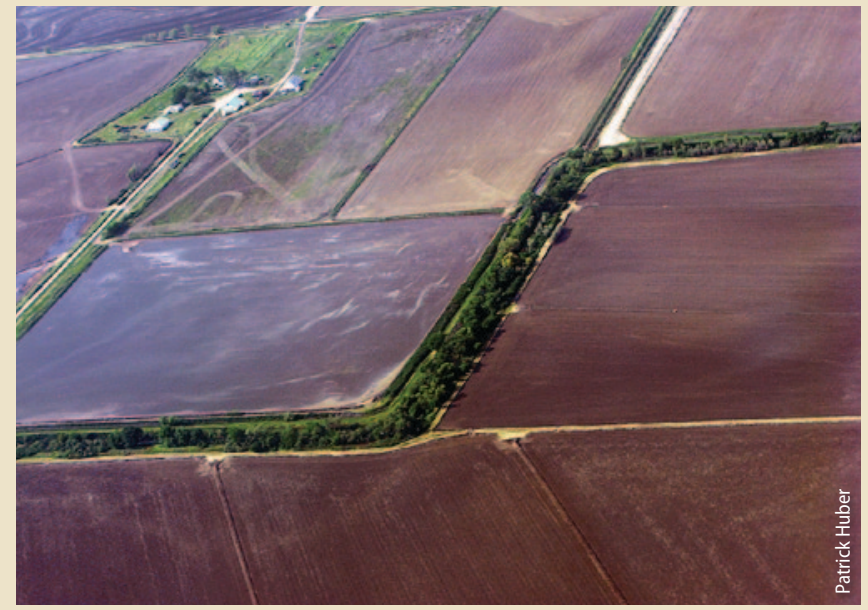

Conservation banks could enable farmers to restore and broaden riparian habitat corridors on the edges of their fields. Above, narrow strips of habitat adjacent to irrigation ditches in Sutter County.
Endowment and financial commitments: To cover the costs of management and monitoring in perpetuity, conservation banks must use a portion of the income from credit sales to set up a nonwasting endowment, in which only the interest on the endowment funds is spent each year. A key issue to address in bank agreements is how to ensure funding of management and monitoring in the first few years of the bank operation, prior to full investment in the endowment from the sale of credits. In addition, if a bank is failing to meet conservation performance goals, financial commitments for managing the bank site may be secured with bonds or other means.

Site management plan: Bank agreements must include a management plan and designated management entity, usually a nongovernmental organization that is responsible for implementing conservation measures — such as habitat management, restoration or creation — and for managing the site in perpetuity. These management responsibilities may be transferred. For example, a banker may provide management during the habitat creation phase and then transfer management to the state or a nonprofit for ongoing maintenance of the site. Bank agreements typically require that annual management reports be submitted to wildlife agencies.

Monitoring plan: Conservation banks establish a monitoring program to determine whether biological goals are being met as well as to inform adaptive management (adjusting management actions in the field credits. Wildlife agencies want to be sure of the ecological justifications for using the conservation bank to offset development impacts anywhere in the service area. Local governments may be concerned about the service area because they usually want the benefits of mitigation for local projects to occur within the county. based on changes detected through monitoring). Monitoring results are included in the annual management reports (Wheeler and Strock 1995). 
However, development of a Natural Community Conservation Plan usually requires 5 to 10 years of analyses and dozens of meetings for scientific and public review. Due to limited state resources, the vast majority of development over the next couple of decades will occur without the Natural Community Conservation Plan level of regional planning (Bunn et al. 2007).

\section{Conservation banking}

Benefits. Expanding the use of conservation banks has the potential to provide conservation design features and benefits similar to those of Natural Community Conservation Plans, but with more efficiency. Creating a conservation bank requires less scientific review and needs to satisfy fewer interests; negotiations usually involve just one landowner, a few stakeholders such as a conservation firm, and the wildlife agencies. The review process and agreement on a proposed conservation bank may be accomplished in about 2 years, as they were in the early years of the program. This is less than one-half the time it typically takes to reach agreement on a regional conservation plan (Ruhl et al. 2005).

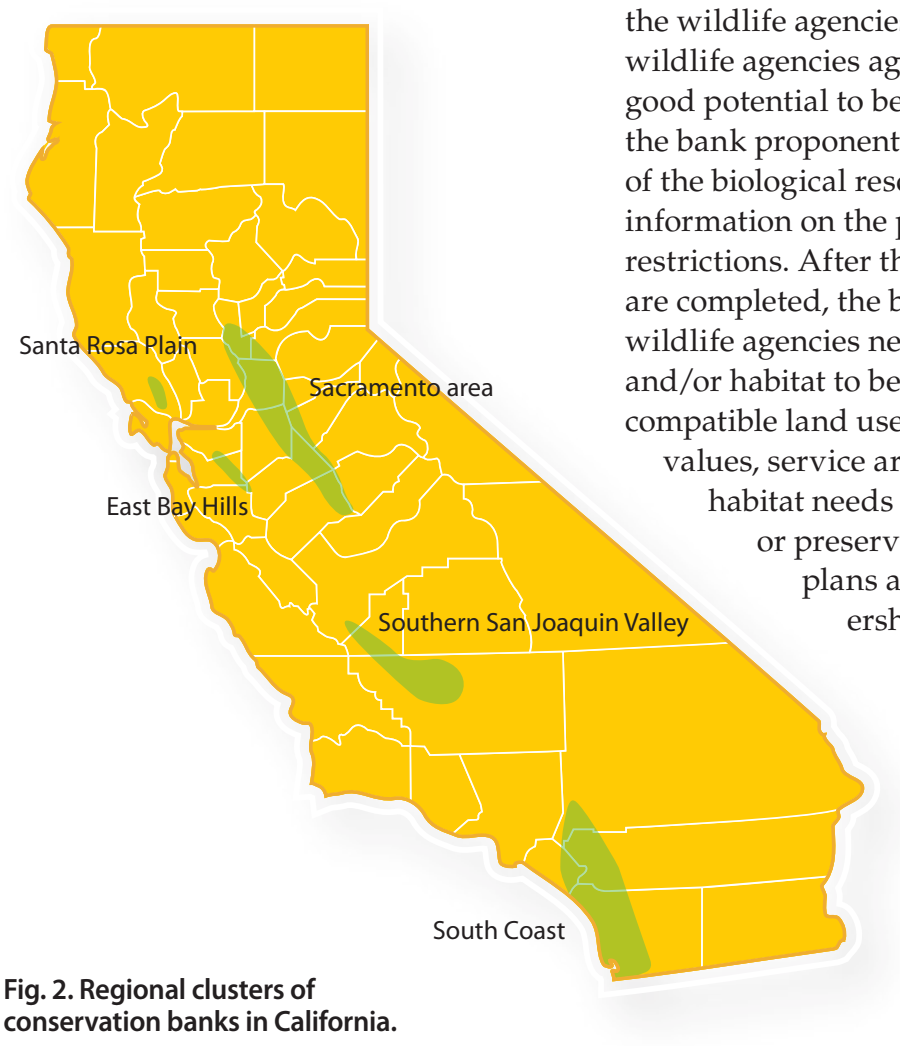
and 2011.

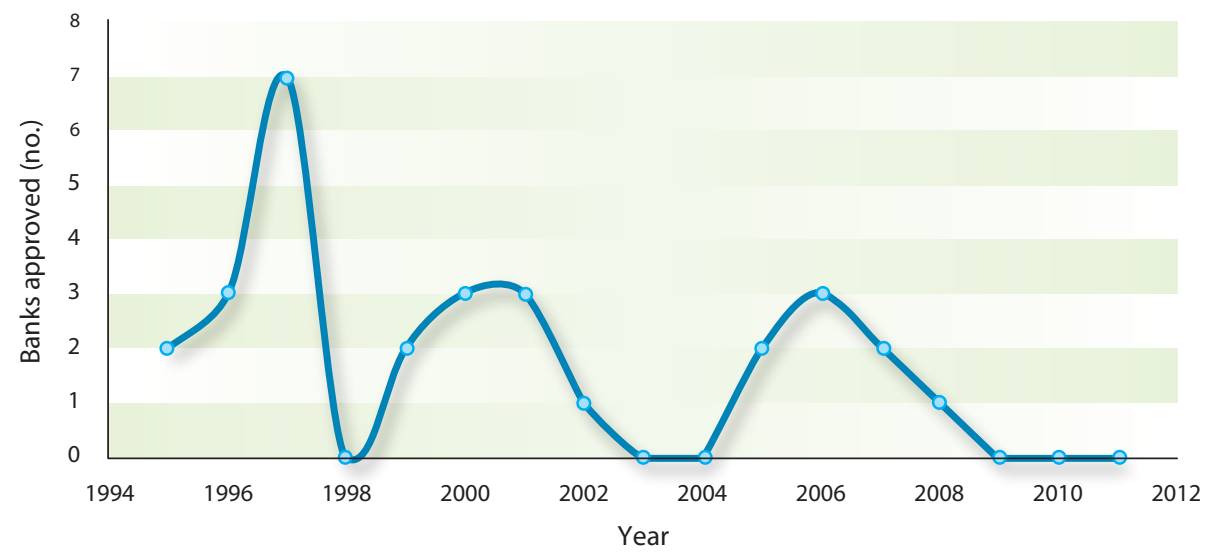

Fig. 1. Number of conservation banks approved each year in the California program between 1995

Establishment. The selection and approval process for most proposed conservation banks usually begins with the bank proponent identifying a property that meets ecological and financial criteria. The proponents are conservation bank practitioners, including small conservation firms, landowners, biological consultants, real estate companies, developers and nonprofit land management organizations. The basic site criteria proponents seek to satisfy are whether a property is good habitat for impacted species within a region and whether there is a good market for conservation credits due to new development. Next, the bank proponent has preliminary discussions with the wildlife agencies (CDFW 2012). If the wildlife agencies agree that the site has good potential to be a conservation bank, the bank proponent prepares assessments information on the property title and restrictions. After the site's assessments are completed, the bank proponent and wildlife agencies negotiate the species and/or habitat to be covered by the bank, mpatible land uses, mitigation credit ues, service area, monitoring plan, itat needs (creation, restoration (cition), management ership or easement.

A draft conservation bank agreement and management plan must be prepared and approved by the agencies. After agreements are approved, and land purchases or easements are executed, credits from the bank may be sold (CDFW 2012).

Status. There is great interest in the potential of conservation banking because - in contrast to the regulatory approach that penalizes landowners for harming species - it creates a market incentive for ranchers and other landowners to conserve wildlife. However, based on the number of new banks approved each year, the program appears to be in decline (fig. 1). Here, we report results of a preliminary investigation into the California Conservation Banking Program, including results of a survey, with particular attention to factors limiting the program's potential to conserve wildlife and natural communities. We also analyze potential reforms to improve the conservation performance of banks while reducing barriers to landowner participation.

\section{Assessing conservation banks}

California has 29 state-approved conservation banks, averaging about 600 acres each (the range is large, from 8 to 6,000 acres). They are clustered in five geographic regions: the South Coast, southern San Joaquin Valley, Sacramento region, East Bay Hills and Santa Rosa Plain (fig. 2). Some of these banks were established within the context of a regional conservation plan, such as a Natural Community Conservation Plan or a Habitat Conservation Plan (HCP). Eight of the 10 banks on the South Coast are within a Natural Community Conservation Plan. Elsewhere, banks were established as stand-alone areas outside of any regional conservation plan; their acreage was selected without benefit of comprehensive regional prioritization of the most ecologically valuable lands. 


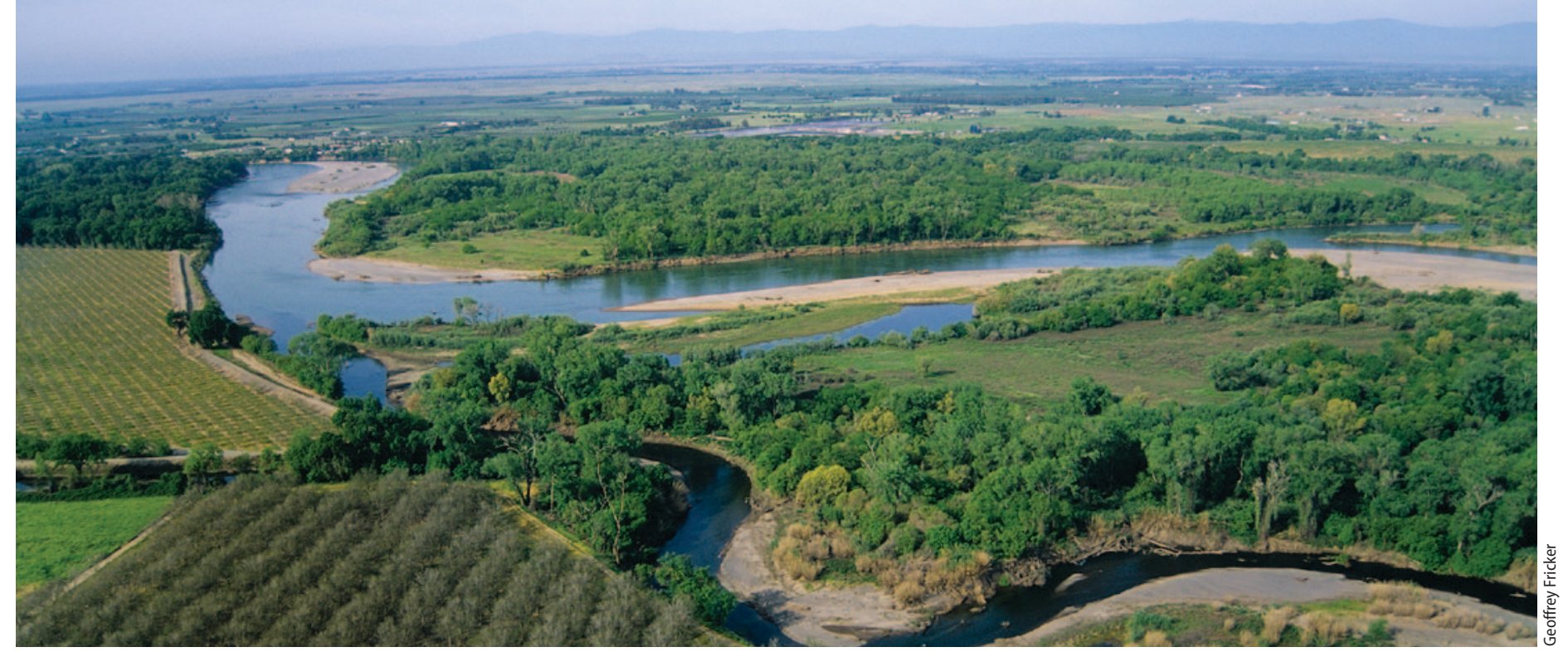

Watercourses and riparian corridors are important areas to protect and restore to maintain habitat connectivity in a region. Conservation banks are an ideal way to conserve or restore riparian habitats along the edges of agricultural lands.

Due to the small number of banks statewide, we did not limit our survey to a statistical sample. Instead, we made the effort to interview most of the individuals involved in developing, managing and providing oversight of all the conservation banks in the California program.

The interviews included 36 individuals who have worked on conservation banks in California over the past 15 years: 20 who work for wildlife agencies (the California Department of Fish and Wildlife, or the U.S. Fish and Wildlife Service) and 16 who work in the private sector, including bank owners, conservation bank firms and land management nonprofits and consultancies:

- The Department of Fish and Wildlife has one staff person assigned to managing conservation banks in each of the six regional offices. We interviewed all current Fish and Wildlife regional conservation bank managers as well as former managers who had been reassigned in the last 5 years. We also interviewed current and former Fish and Wildlife deputy directors and headquarters staff who have engaged in management of the conservation bank program.

- The U.S. Fish and Wildlife Service has only a couple of field staff devoted to conservation banks in California. We interviewed two senior managers involved in conservation banks in the Pacific Southwest regional office in Sacramento and two field staff serving Southern California.

- With regard to conservation banking practitioners, we attempted to interview managers covering all of the conservation banks in the state. From bank agreement records, we obtained names of the conservation banking firms or private companies and the managers for all of the conservation banks. We completed interviews of current owners, management consultants or management firm representatives of $79 \%$ of the banks.

All interviews were conducted by a single investigator either in person or by telephone during December 2011 and January 2012. Answers were summarized and recurring responses were tallied, scoring one point for each person who gave that particular response. We then ranked the answers by total scores (figs. 3 to 6). Respondents were identified as either associated with wildlife agencies or conservation bank practitioners, so differences in responses or priorities of wildlife agencies versus the private sector could be analyzed.

Survey questions were designed to (1) assess the criteria used to select new conservation banks and identify what changes may be needed to ensure that the

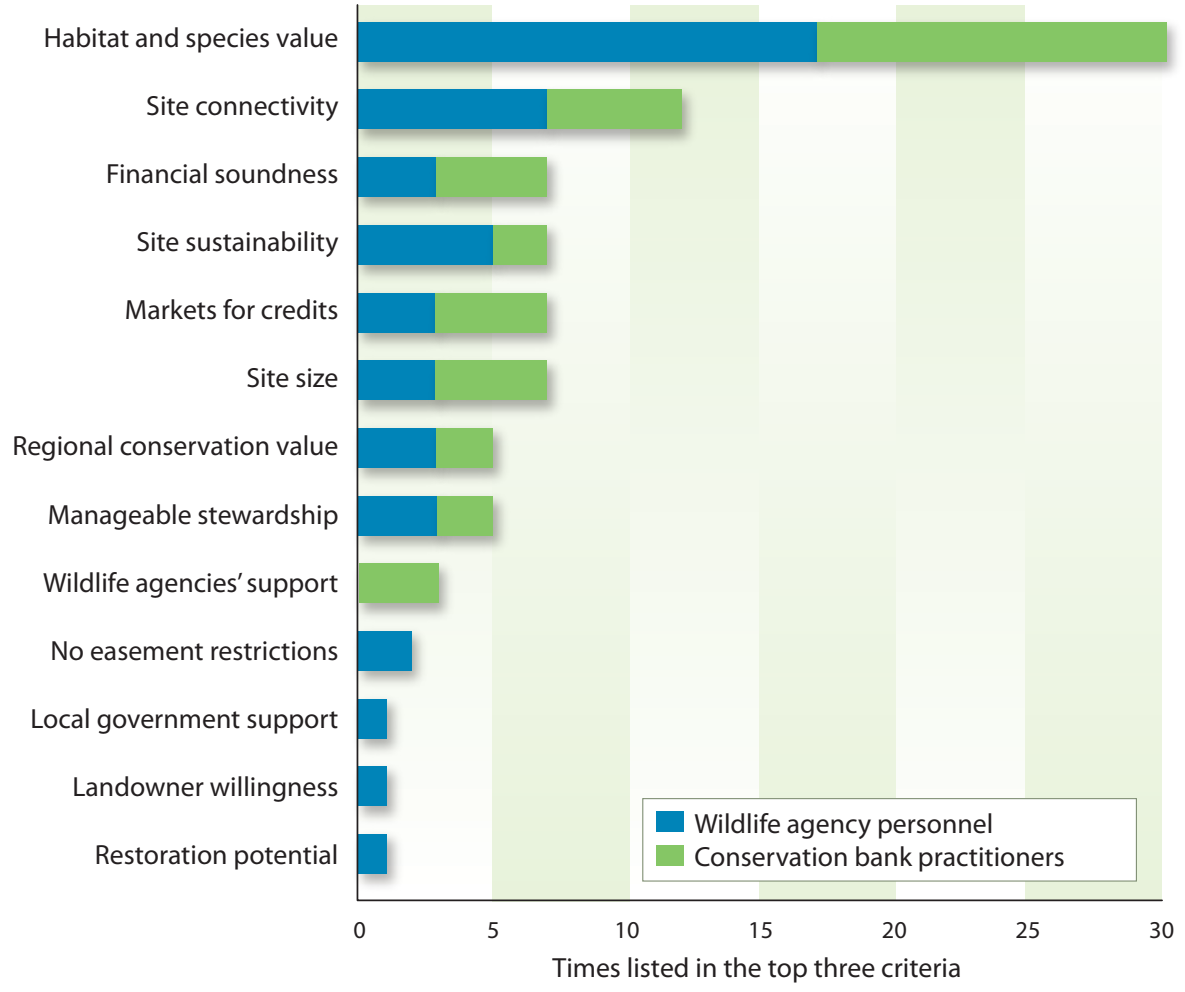

Fig. 3. Most important criteria for selecting and approving conservation banks identified by survey respondents. 
best sites are selected, (2) assess the challenges and barriers to implementing an effective program and (3) identify policy changes that will improve the program.

For each of the 29 bank sites of the California Conservation Banking Program approved by 2011, we also reviewed bank agreements, biological assessments, management and monitoring plans, and annual monitoring reports from the files of regional offices of the California Department of Fish and Wildlife. With regard to monitoring, we assessed whether covered species were useful indicators of the impact of conservation measures (Bunn, unpublished). We also compared regional conservation values of the banks based on the estimates of size, habitat connectivity and habitat diversity (Bunn, unpublished).

\section{Barriers and reforms}

The wildlife agency staff and conservation bank practitioners have very firm ideas regarding the difficulties of conservation banking, and most also had recommendations for reforms.

Lack of agency program staff

Process too long, admin burden and uncertainty

Cost and assessing financial risks

Ensuring conservation success

Determining service area

Getting agencies to agree

Determining credit value and release schedule

Finding sites to meet habitat and species criteria

Assessing market for credits

Assessing risks that threaten the physical site including title

Working with landowners not affiliated with CB firm

Lack of guidance on what agencies want

Negative perception of program (internally and externally)

Gaining legal access to site for review

Communications between banks and agencies

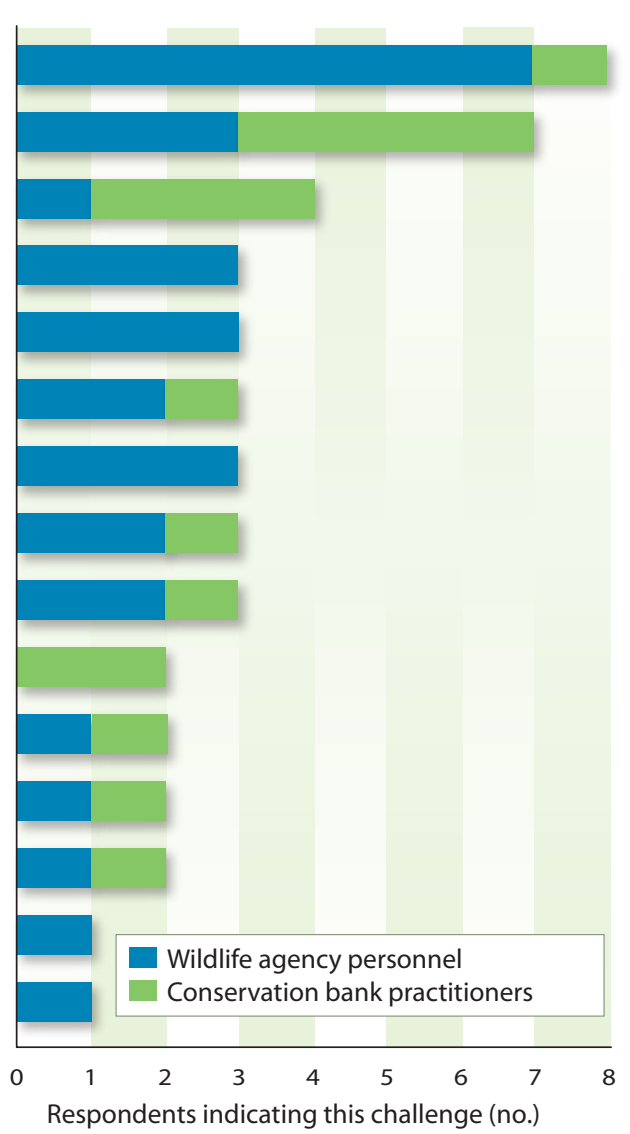

Fig. 4. Challenges of site selection and approval identified by respondents.

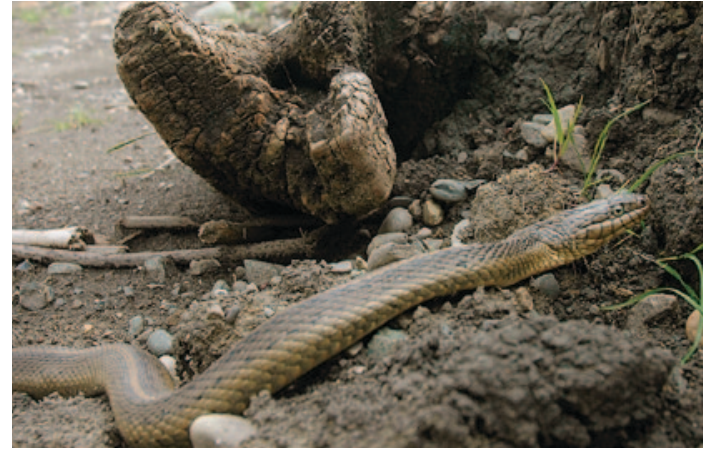
in the California program.
Site selection criteria. Survey respondents generally agreed on key criteria for selecting a bank site (fig. 3). Among 14 criteria identified, the top two were quality of habitat (score $=29$ ) and site connectivity to similar habitats within the region (score $=12$ ). The next most common criteria were site size, market for credits, and financial soundness and sustainability (score $=7$ for each). As expected, conservation banking practitioners emphasized the importance of the market for credits and financial risks more often than wildlife agency respondents.

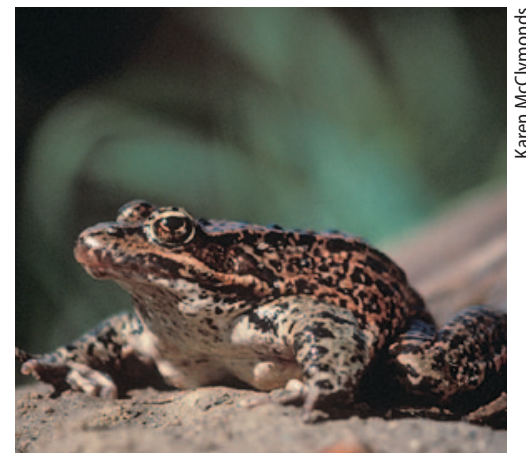

The giant garter snake and red-legged frog are species of concern protected by conservation banks

Barriers to site selection or approval. Interviewees were asked to identify the three greatest challenges to selecting or approving a conservation bank site (fig. 4). Fifteen different challenges were identified. Among all respondents, the three most frequently mentioned were (1) lack of staff in wildlife agencies dedicated to handling conservation banks (score $=8$ ), (2) the long and bureaucratic approval process (score $=7$ ) and (3) difficulty in assessing costs and financial risks (score $=4$ ). The next most common challenges identified were ensuring conservation success, determining service area, getting agencies to agree, determining credit value and release schedule, finding sites that meet habitat and species criteria, and assessing the market for credits (score $=3$ for each).

Tough issues to resolve. Respondents identified 19 issues that were the most difficult to resolve for approval of a conservation bank (fig 5). Of these, the two identified most often by wildlife agency respondents were reaching agreement on the number of credits warranted by the wildlife values at the site $($ score $=7$ ) and determining the service area $($ score $=6$ ). Conservation banking practitioners had scattered responses, with only one or two points each identifying a dozen issues, including title and easement issues (score $=2$ ), estimating cost (score $=2$ ) and length of the process (score $=2$ ) (fig. 5). The number of challenges identified highlights the complexity of the process. Negotiations regarding approval can be stalled over disagreement on any or several of these difficult issues.

Major barriers to approval. Conservation banking practitioners most frequently said that the number one challenge is the lengthy approval process, requiring 2 to 7 years. The wildlife agencies 
indicated that the excessive length of the process is mainly due to the lack of staff dedicated to the program, which slows site reviews and conservation bank application processing. Conservation banking practitioners said that the second most difficult challenge is assessing the costs and financial risks of a proposed bank.

Agreement on major barriers. Considering all of these challenges and issues, wildlife agencies and conservation banking practitioners were in close agreement on the major barriers to the development of new conservation banks (fig. 6). The most commonly identified barriers were (1) the approval process is too long (score =16), (2) the upfront and management costs are too high (score $=12)$, (3) a market for credits is lacking (score $=7$ ) and (4) parties disagree over who should hold the bank endowment for management in perpetuity (score $=6$ ).

Guidelines for creation. Wildlife agencies have provided very general guidelines for the selection of conservation bank sites. When asked if they recommended changes to state and federal guidance on conservation bank selection criteria, three-quarters of the wildlife agency respondents and more than half of the conservation banking respondents recommended changes. The most frequent recommendation by wildlife agency respondents was to include clear selection criteria in regulations (score $=7$ ). The next most common point, emphasized more by conservation banking practitioners, was that criteria must have flexibility due to the tremendous variability of regions and environmental conditions. (Data not shown.)

Reforms to facilitate creation. When asked to recommend changes to the site selection and approval process that would facilitate creation of conservation banks with high habitat and ecological value, the most common response by far was to determine the highest-priority lands for conservation in a region before designating banks there (score $=10$ ). The next most common responses were early communication between bankers and agency staff regarding the site of a proposed bank (score $=4$ ) and adding dedicated conservation banking program staff in the agencies (score $=3$ ). (Data not shown.)

Major barriers to long-term viability.

We also asked respondents to assess the greatest challenges of managing or

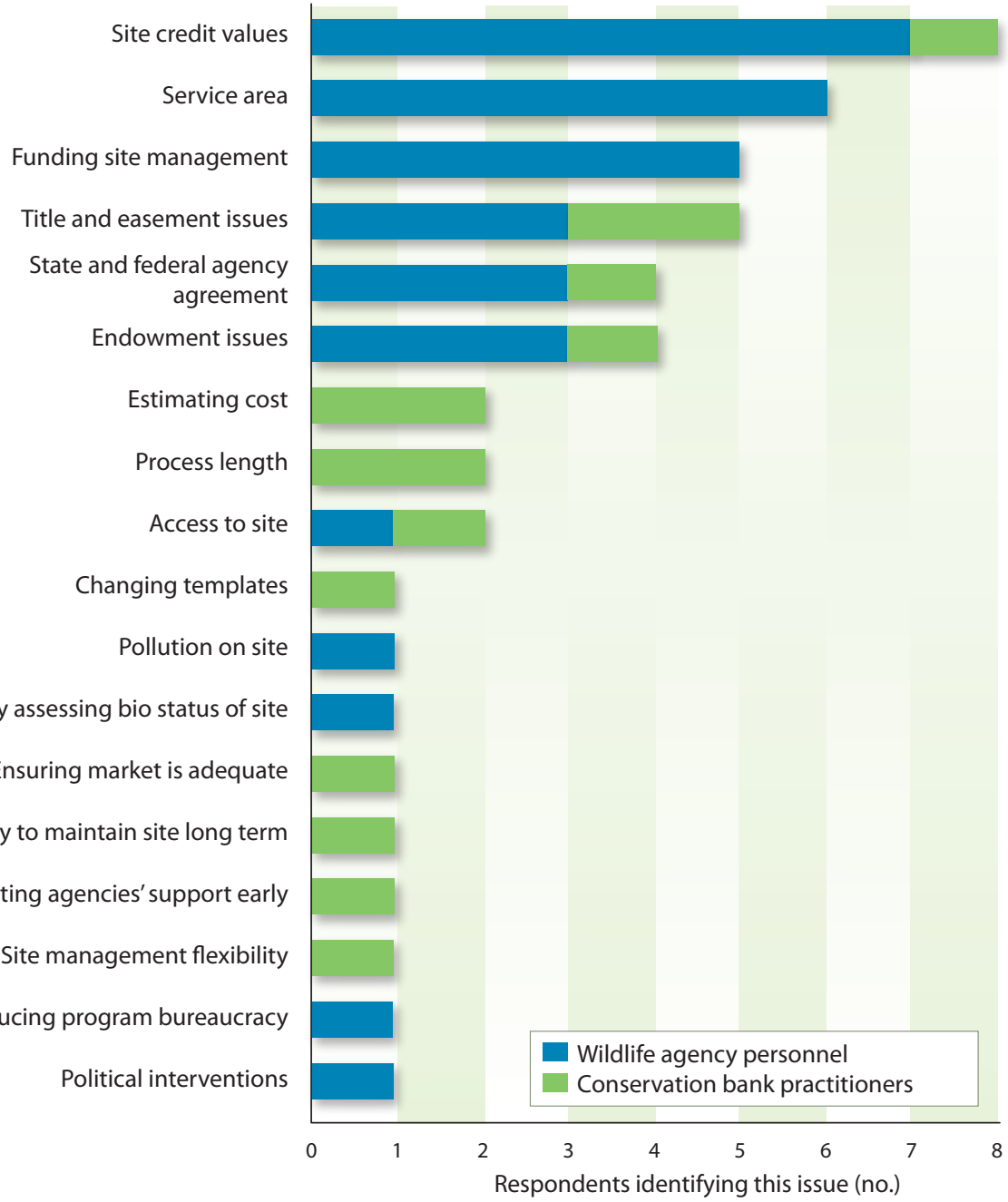

Fig. 5. Most difficult issues to resolve for approval of a conservation bank identified by survey respondents.

Approval process too long

Upfront and management costs

Lack of market

Lack of dedicated agency staff

Endowment disagreements

Lack of willing sellers

Process uncertainty

Landowner perceptions

Lack of regional plan

Conflicts with NCCPs/HCPs

Difficult process

Disagreement on management

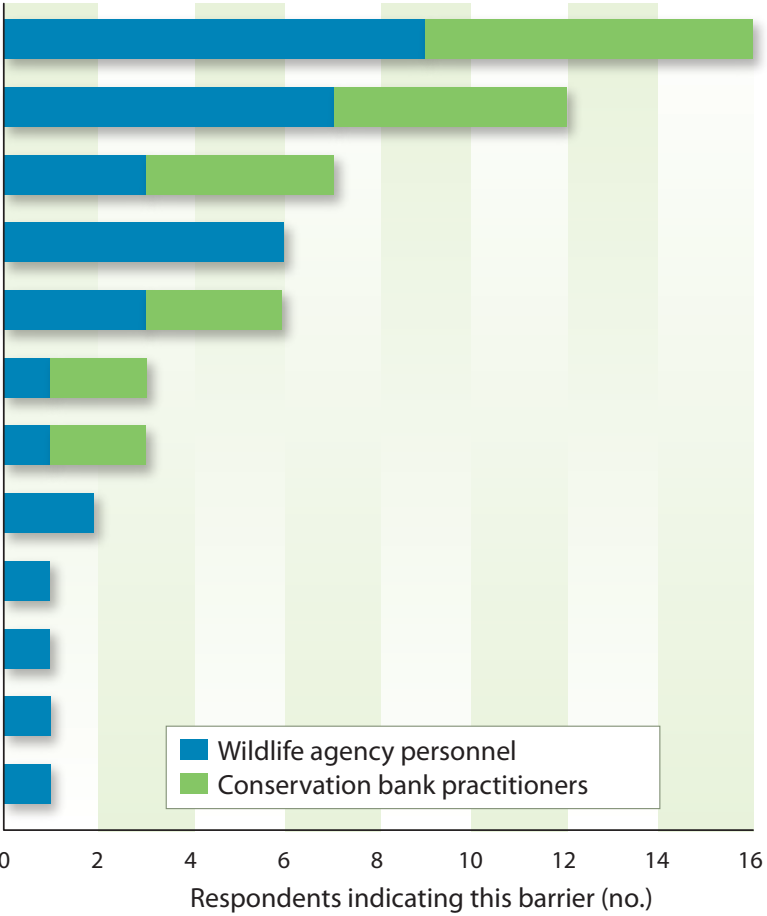

Fig. 6. Barriers to new conservation banks identified by survey respondents. 
supervising established banks. Lack of staff was the most common response of wildlife agency respondents (score $=14$ ). Some wildlife agencies also pointed to weak monitoring programs and difficulty making changes as part of adaptive management. Conservation banking practitioners tended to highlight site operational issues, including incompatible uses of adjacent lands, controlling invasive vegetation, preventing unauthorized use and keeping management costs down. (Data not shown.)

Reforms to facilitate long-term viability. Interviewees were asked if there are any issues that need to be resolved to ensure the long-term viability of the conservation bank program. Three-quarters of the interviewees - including $80 \%$ of the wildlife agency and $66 \%$ of the conservation banking practitioner respondents said that reform would be required for the long-term viability of the program. (Data not shown.)

Wildlife agency respondents said that the most important issues to resolve were adding dedicated agency staff (score $=$ 8) and establishing new policy about who should be permitted to hold endowments (score $=4$ ). Conservation banking practitioners said that the most important issues to resolve for the program's long-term viability were agency cooperation and consistency (score $=5$ ) and establishment of regional management of conservation banks (score $=4)$. Both wildlife agency and conservation banking practitioner respondents highlighted the need for common standards for conservation banks. Wildlife agency respondents are more inclined to suggest that these standards and other requirements of the conservation bank program be formalized in statutes and regulations.

Evaluating conservation banks. In the 1990s, there were high expectations that California's innovative conservation banking program would provide an effective market-driven mechanism for developers, ranchers and other landowners to conserve species and natural communities impacted by rapid development. Conservation banking was authorized with just a brief executive policy statement; there was no legislative deliberation or mandate (Wheeler and Strock 1995). Now with a record of 18-plus years, it is time to evaluate whether the program is meeting expectations and contributing to achieving conservation goals.

We analyzed the challenges and potential improvements of the California program with both the conservation and financial requirements in mind. In ad- planned, the wildlife agencies will be under pressure from the public and policymakers to discontinue the program. If the financial risks of conservation banking are too high, the private sector will cease to develop new banks.

Ecological value. The 29 conservation banks under the California program were established under a wide variety of environmental circumstances and differ in their regional ecological value. Even within regions (fig. 2), the value of banks varies widely based on the ecological criteria of size of the site, connectivity to adjacent natural lands and biodiversity. For example, the ecological values of sites on the Santa Rosa Plain were similar, while values varied widely among sites in the Central dition to conserving species, program success requires that the business of conserving priority lands and achieving conservation objectives be profitable for landowners and conservation banking firms. If conservation banks fail to conserve species and natural communities as

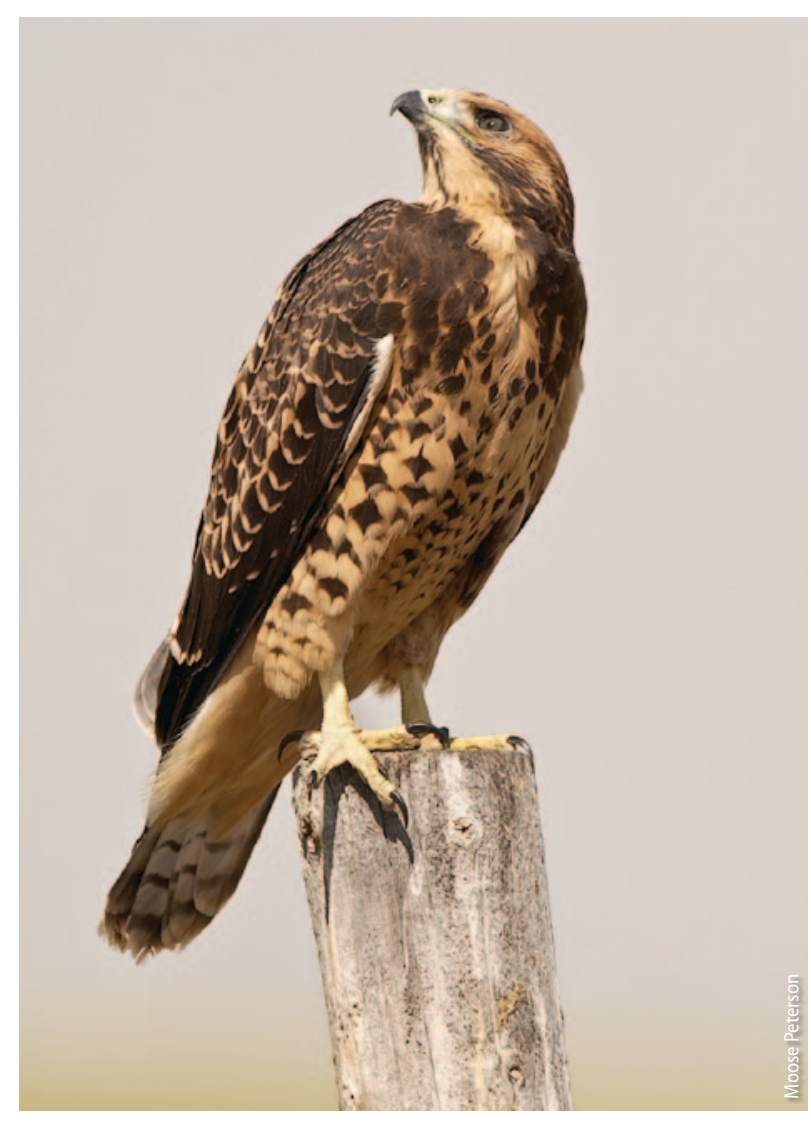

The California Conservation Banking Program protects Swainson's hawk, another species of concern in the state.
Valley. Eight of the 10 banks on the South Coast were established within the context of a regional conservation plan. Still other banks were established as stand-alone projects without the benefit of any regional plan or comprehensive prioritization of ecologically valuable areas.

Monitoring. Conservation banks generally support only very limited monitoring programs, and very basic annual or seasonal surveys of species and parameters such as water level in vernal pools or depth of thatch in upland grasslands. Monitoring programs will provide data of limited value unless they are carefully designed, with defined goals, hypotheses and consideration of statistical power (Field et al. 2005; Legg and Nagy 2006; Lindenmayer and Likens 2010; Noon 2003). A preliminary review of the monitoring plans and annual monitoring reports for each bank found that monitoring usually focuses on the covered species for which a bank was established. However, a bank's conservation measures are not likely to be related to the abundance of highly mobile at-risk species such as Swainson's hawk (Buteo swainsoni), burrowing owl (Athene cunicularia) and kit fox (Vulpes macrotis) because they have home ranges much larger than the typical bank. Furthermore, monitoring of such species at bank properties is not 
likely to elucidate whether changes in abundance are due to factors at the site or due to regional factors.

\section{Challenges and key reforms}

The results of our survey indicate that both the private and public sectors of the conservation banking community understand the principles of conservation biology and generally agree on the important ecological and financial criteria for good bank sites (fig. 3). This is significant because efforts to improve a program involve change, and change is always easier when the stakeholders agree on the goals. Most survey respondents agree that the conservation banking program has numerous challenges and that changes are needed to the site approval process, program standards, guidelines and policies.

Challenges. The approval of new conservation banks and long-term management of established banks face many challenges (table 1). Conservation bankers identified the lengthy and uncertain review process as the number one challenge to gaining approval for a new conservation bank (figs. 4 and 6). By a wide margin, wildlife agency staff identified the number one problem as the lack of staff assigned to the program, which is also partly responsible for the slow review process. Several agency staff also agreed with the bankers that the lengthy process is a major problem.

Altogether, our survey of the conservation banking community and our analyses of the bank monitoring programs and site ecological parameters identified 22 site selection challenges and 15 management challenges (table 1), all of which can be linked to three fundamental problems: (1) lack of clear standards and regulations, (2) lack of sufficient well-trained program-dedicated wildlife agency staff and (3) the inefficiency and ecological constraints of approving and managing stand-alone banks. Solving these three problems will solve or reduce many of the other issues identified by wildlife agency staff, the private sector and our program analyses (table 1). Addressing these problems will also enhance the long-term viability of conservation banking as an effective tool for mitigating the impacts of development.

Key reforms. Three actions will address these fundamental problems, and many of the challenges that face
TABLE 1. Three major policy changes that address most of the challenges and barriers of conservation banking identified by survey respondents

\begin{tabular}{|c|c|c|c|}
\hline Site selection and approval challenges & $\begin{array}{c}\text { Policy 1. Adopt } \\
\text { standards and } \\
\text { regulations }\end{array}$ & $\begin{array}{l}\text { Policy } 2 \text {. Fund } \\
\text { adequate } \\
\text { program staff }\end{array}$ & $\begin{array}{l}\text { Policy } 3 . \\
\text { Require regional } \\
\text { planning }\end{array}$ \\
\hline Lack of agency staff & $\mathbf{\square}$ & $\mathbf{\square}$ & \\
\hline Long and difficult approval process & $\mathbf{\square}$ & $\mathbf{\square}$ & $\square$ \\
\hline Upfront and ongoing costs & $\mathbf{\square}$ & $\mathbf{\square}$ & \\
\hline Process uncertainty and risk & $\mathbf{\square}$ & $\mathbf{\square}$ & $\mathbf{\square}$ \\
\hline Ensuring good site management & $\mathbf{\square}$ & $\mathbf{\square}$ & \\
\hline Determining service area & $\mathbf{\square}$ & & $\mathbf{\square}$ \\
\hline Getting agencies to agree & $\mathbf{\square}$ & & $\mathbf{\square}$ \\
\hline Determining credit value and schedule & $\mathbf{\square}$ & & $\mathbf{\square}$ \\
\hline Selecting sites with good ecological values & $\mathbf{\square}$ & $\mathbf{\square}$ & $\mathbf{\square}$ \\
\hline Lack of regional conservation plan & & & $\mathbf{\square}$ \\
\hline Conflicts with NCCPs and HCPs & $\mathbf{\square}$ & & $\mathbf{\square}$ \\
\hline Assessing market for credits & $\mathbf{\square}$ & & $\mathbf{\square}$ \\
\hline \multicolumn{4}{|l|}{ Lack of credit market } \\
\hline Assessing threats to site & & $\mathbf{\square}$ & $\mathbf{\square}$ \\
\hline Endowment disagreement & $\mathbf{\square}$ & & \\
\hline \multicolumn{4}{|l|}{ Lack of willing sellers } \\
\hline Working with landowners without banker & & $\mathbf{\square}$ & \\
\hline Disagreement on site management & $\mathbf{\square}$ & & \\
\hline Lack of agency guidance of priority sites & $\mathbf{\square}$ & & $\mathbf{\square}$ \\
\hline Negative perception of program & & $\mathbf{\square}$ & $\mathbf{\square}$ \\
\hline Gaining access to sites for review & $\mathbf{\square}$ & & \\
\hline Communications between banks and agencies & & $\mathbf{\square}$ & $\mathbf{\square}$ \\
\hline Total & 15 & 10 & 13 \\
\hline \multicolumn{4}{|l|}{ Management challenges } \\
\hline Lack of agency staff & $\mathbf{\square}$ & $\mathbf{\square}$ & \\
\hline Implementing adaptive management & & $\mathbf{\square}$ & $\mathbf{\square}$ \\
\hline Weak monitoring program & $\mathbf{\square}$ & $\mathbf{\square}$ & $\mathbf{\square}$ \\
\hline Incompatible uses of adjacent lands & & & $\mathbf{\square}$ \\
\hline \multicolumn{4}{|l|}{ Controlling invasive vegetation } \\
\hline \multicolumn{4}{|l|}{ Preventing unauthorized use } \\
\hline Lack of site review guidelines & $\mathbf{\square}$ & & $\mathbf{\square}$ \\
\hline Lack of management and monitoring regulations & $\mathbf{\square}$ & & $\mathbf{\square}$ \\
\hline Difficulty in accessing endowments & & & $\mathbf{\square}$ \\
\hline \multicolumn{4}{|l|}{$\begin{array}{l}\text { Lack of neighbor cooperation for } \\
\text { endangered species }\end{array}$} \\
\hline $\begin{array}{l}\text { Getting agency support for changes to solve } \\
\text { problems }\end{array}$ & $\mathbf{\square}$ & $\mathbf{\square}$ & $\square$ \\
\hline \multicolumn{4}{|l|}{$\begin{array}{l}\text { CDFW ownership constrains management options } \\
\text { like grazing }\end{array}$} \\
\hline Achieving conservation goals & & $\square$ & $\mathbf{\square}$ \\
\hline \multicolumn{4}{|l|}{ Managing fire } \\
\hline \multicolumn{4}{|l|}{ Risk of site condemnation for rights of way } \\
\hline Total & 5 & 6 & 8 \\
\hline
\end{tabular}


conservation banking: (1) the enactment of state conservation banking standards in statutes and regulations, (2) securing funding for adequate agency staff and (3) establishing a regional approach to planning and monitoring. These reforms are necessary if conservation banking is to achieve its potential for mitigating the negative impacts of development on species of concern.

\section{Establishing legal standards}

Wildlife agency personnel and conservation banking practitioners indicated that a high priority for reform was establishing standards for approving new banks, designing and evaluating monitoring programs and reviewing conservation performance. Conservation banking practitioners also highlighted the importance of guidelines or standards being consistent and not changing from year to year once the approval process has begun for a particular site. From the conservation banking practitioner point of view, it is critical that standards do not change after they have invested a year or more on studies and negotiations for easement, endowment and management agreements. Clear and stable standards reduce uncertainty and the length of the approval process - two of the greatest barriers and risks for landowners and conservation bank firms.

Clear standards also assist the agency reviewers and lead to more consistent evaluations of proposed conservation banks. However, wildlife agencies and conservation banking practitioners emphasized that standards must have some flexibility because land use and ecological circumstances are so varied from one region to another and among different natural communities. While most wildlife agencies and conservation banking practitioners agree that standards would improve the program, the latter are reluctant to suggest that those standards be adopted in formal regulations.

However, in January this year, a new state law (SB 1148 ) established clear guidance for one aspect of the conservation banking program, the application process and timeline. This conservation banking statute is an important first step, and regulations will help to eliminate or reduce many of the major challenges identified by the conservation banking community (fig. 6).

\section{Wildlife agency staffing}

The new law may also help to address inadequate staffing by mandating that fees be assessed to cover costs of the program. This increases the likelihood that funding will be provided for dedicated program personnel. Legislatively mandated programs have higher priority for funding and staffing. Additional laws and regulations are still needed to standardize the process for reaching agreement on some of the most contentious elements of banks: regional conservation priorities, credit value and schedule, service area, and monitoring requirements.

\section{Regional planning}

The state and federal wildlife agencies should develop regional conservation plans for conservation banking. This would reduce or solve many of the major challenges of the bank selection and approval process and the ongoing management of approved sites (table 1). While conservation banking was originally conceived as a positive alternative

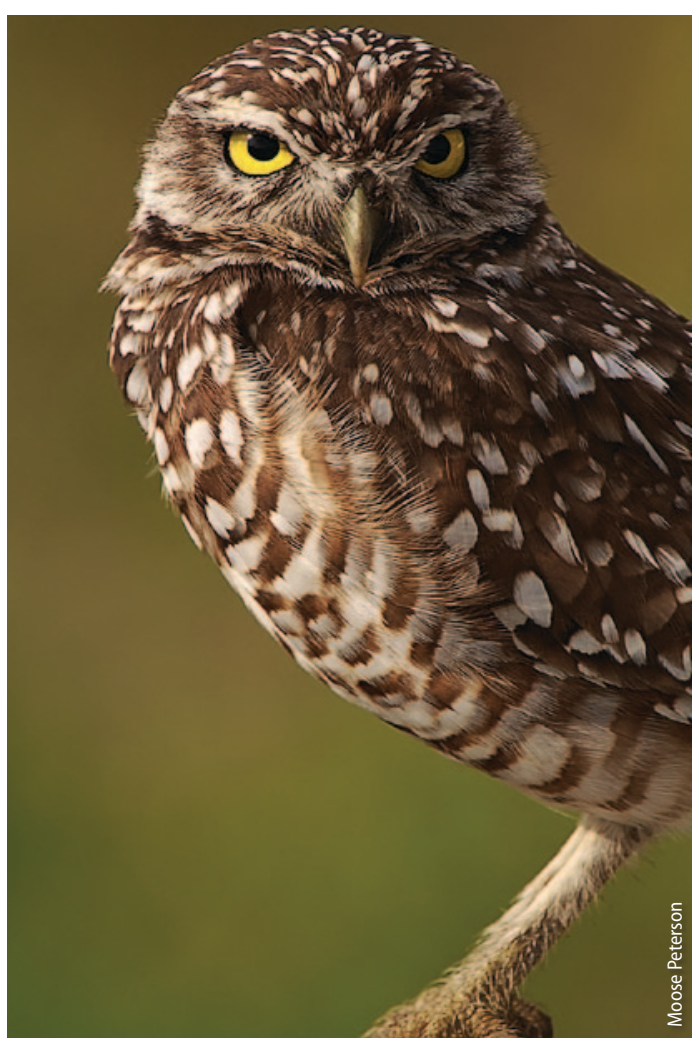

California rangelands managed under a conservation bank can provide excellent habitat for burrowing owls. Burrowing owls benefit from several conservation banks in the Central Valley. to project-by-project mitigation, the creation of stand-alone conservation banks suffers many of the limitations of single project mitigation. Several of the earliest banks were developed in the conservation planning area of a Natural Community Conservation Plan in Southern California to protect coastal sage scrub habitat of the threatened California gnatcatcher among other species. As such, these banks could be evaluated for their regional conservation value and their contribution to the designed reserve network of the regional plans.

Drawbacks of stand-alone banks. More recently approved banks are stand-alone banks. The ecological evaluation of standalone banks is based on a biological assessment of the site and site visits. The initial biological assessments of conservation banks, performed early in the site review process, are generally very basic and lack a comprehensive evaluation of the regional ecological context as well as a site's contribution to regional biodiversity and connectivity (Noss et al. 1997). Lacking the regional analyses, sites cannot be compared and ranked, and inferior sites may be approved. This may explain why

the ecological value of sites within a region, like the Central Valley, varies widely. In this case, the conservation banking program is not achieving its full potential.

The lack of regional analyses and planning also makes the task of objectively evaluating the conservation value of a proposed bank very difficult. Conservation bankers and agency scientists conduct their own analyses, and this can lead to much disagreement on the conservation value of a site, delaying or stalling the review process. Stand-alone banks may not provide the best ecological value if they are reviewed apart from a regional analysis of conservation priorities or at a more relevant ecological scale (du Toit 2010).

Monitoring. Regional planning and coordination will also improve monitoring of bank performance. Conservation banks must have a monitoring program (USFWS 2003; Wheeler and Strock 1995). There are two problems with establishing a separate monitoring program for each conservation bank. First, the monitoring at the scale of a single bank site, 
without comparison to regional species or habitat trends, is unable to distinguish the impacts of conservation measures from those of regional environmental changes (du Toit 2010; Noon 2003; Bunn, unpublished). Second, banks have very limited funding for monitoring, and it is not efficient to manage separate monitoring programs for each bank. Allowing landowners or conservation bank firms to pool resources for regional monitoring would be more efficient and would provide better data to assess the impact of conservation measures at the site level versus changes caused by regional factors.

Conservation priorities. Regional planning could pre-identify regional conservation priorities, important reserve areas and corridors, biodiversity hotspots and threats to wildlife resources (Kiesecker et al. 2009). This kind of prior regional analysis would expedite the assessment of credit values, determination of appropriate service area and agreement among regulatory agencies and bankers on the conservation value of a proposed bank site relative to the other potential sites in a region. A portion of the upfront fund commitment for each bank and a portion of the bank management funds should be pooled in a regional endowment to support regional planning and monitoring of conservation banks.

Nationwide, there are now over 120 approved conservation banks covering 100,000 acres. State wildlife departments and the U.S. Fish and Wildlife Service continue to approve more conservation banks each year. Lessons learned from the California Conservation Banking Program can help guide efforts to

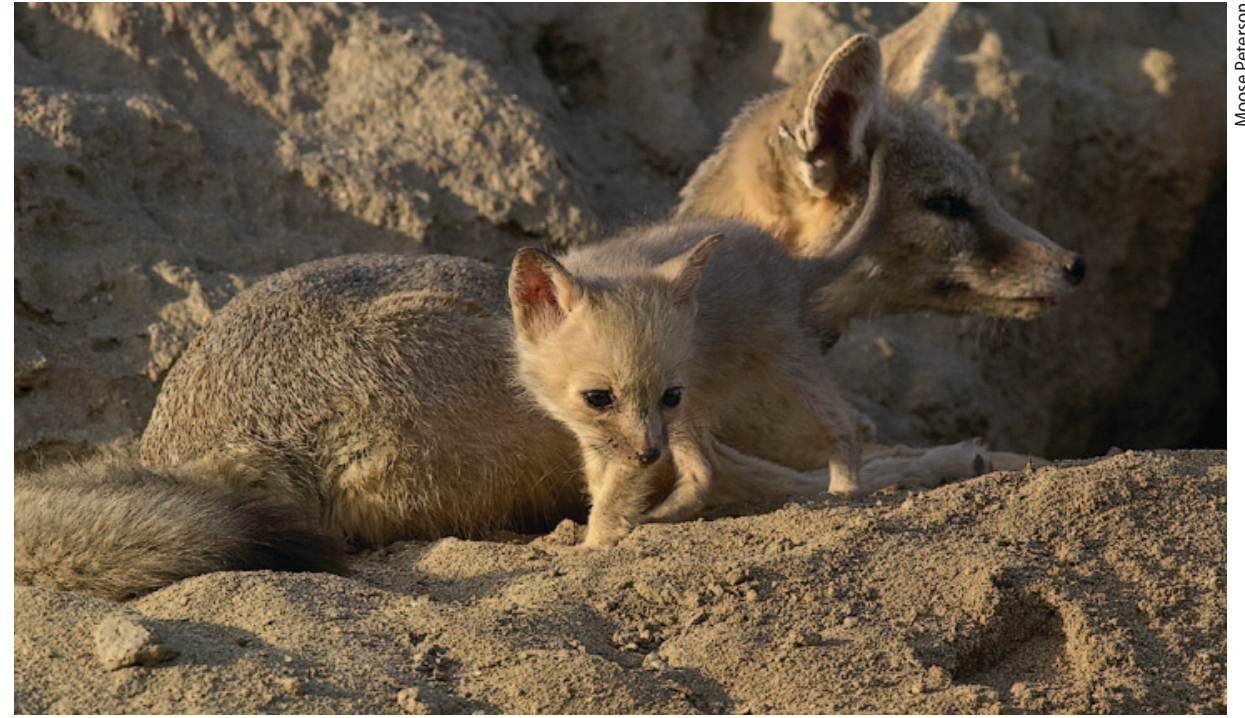

Conservation banks may be one of the best mechanisms for protecting key habitat of San Joaquin kit foxes on private lands.

improve such programs nationwide. If it is to be a successful mechanism for mitigation, conservation banking must achieve conservation goals and be profitable for landowners and banking practitioners. Making conservation banking programs a viable economic option for more landowners will require new policies to establish clear and stable standards, and to fund dedicated agency staff to coordinate the review process for proposed banks and to supervise established banks. Policies requiring regional approaches to prioritize lands and design monitoring programs would both increase the performance of conservation banking and make site selection and approval more efficient. Without program reform, the program is too difficult or risky for most landowners, and many properties with tremendous wildlife value may never be available for conservation banking. The new conservation banking law is an important first step, but does not yet provide guidance on prioritizing sites, nor on addressing regional planning or monitoring.

D. Bunn is Researcher and Project Manager, Wildlife Health Center, School of Veterinary Medicine; M. Lubell is Professor, Department of Environmental Science and Policy; and C.K. Johnson is Associate Professor, Wildlife Health Center, School of Veterinary Medicine, all at UC Davis.

We wish to thank the California Department of Fish and Wildlife staff in the Habitat Conservation Planning Branch, the Biogeographic Data Branch and the regional offices for their assistance. We especially want to thank Brenda Johnson, Tom Lupo, Cara Roderick and Katrina Valerio for their assistance.

\section{References}

Atkinson AJ, Trenham PC, Fisher RN, et al. 2004. Designing Monitoring Programs in an Adaptive Management Context for Regional Multiple Species Conservation Plans. USGS Western Ecological Research Center.

Bunn D, Mummert A, Hoshovsky M, et al. 2007. California Wildlife: Conservation Challenges, California's Wildlife Action Plan. California Department of Fish and Game.

[CDFW] California Department of Fish and Wildlife. 2012. Conservation Banking. www.dfg.ca.gov/habcon/conplan/mitbank/cmb_genpolicies.html (accessed January 2012).

du Toit JT. 2010. Considerations of scale in biodiversity conservation. Anim Conserv 13:229-36.

Field SA, Tyre AJ, Possingham HP. 2005. Optimizing allocation of monitoring effort under economic and observational constraints. J Wildlife Manage 69(2):473-82.

Kiesecker JM, Copeland H, Pocewicz A, Mckenney B. 2009. Development by design: Blending landscape level planning with mitigation hierarchy. Front Ecol Environ 8:261-6.

Legg C, Nagy L. 2006. Why most conservation monitoring is, but need not be, a waste of time. J Environ Manage 78:194-9.

Lindenmayer DB, Likens GE. 2010. The science and application of ecological monitoring. Biol Conserv 143:1317-28

Mead DL. 2008. History and theory: The origin and evolution of conservation banking. In: Carroll N, Fox J, Bayon R (eds.). Conservation \& Biodiversity Banking: A Guide to Setting Up and Running Biodiversity Credit Trading Systems. Sterling, VA: Earthscan

Noon B. 2003. Conceptual issues in monitoring ecological resources. In: Bush DE, Trexler JC (eds.). Monitoring Ecosystems, Interdisciplinary Approaches for Evaluating Ecoregional Initiatives. Washington, DC: Island Press.
Noss RF, O'Connell MA, Murphy DD. 1997. The Science of Conservation Planning, Habitat Conservation Under the Endangered Species Act. Washington, DC: Island Press.

Pollack D. 2001. Natural Community Conservation Planning (NCCP), The Origins of an Ambitious Experiment to Protect Ecosystems. California Research Bureau, CRB01-002

Ruhl JB, Glen A, Hartman D. 2005. Practical guide to habitat conservation banking law and policy. Nat Resour Environ 20:26.

[USFWS] US Fish and Wildlife Service. 2003. Guidance for the Establishment, Use and Operation of Conservation Banks. Memorandum, May 2.

Wheeler DP, Strock JM. 1995. Official Policy on Conservation Banks. California Resources Agency. http://ceres. ca.gov/wetlands/policies/mitbank.html (accessed December 2010) 